\title{
Terbum
}

36 (2019) 373-407

\section{Ewa Osek}

Katolicki Uniwersytet Lubelski Jana Pawła II ewaosek@kul.pl, ORCID: 0000-0002-9407-4435

\section{AićvIOS W LITERATURZE HELLEŃSKIEJ: od Platona do Pseudo-Timajosa}

The Aí́viıs in Hellenic Literature:

From Plato to Pseudo-Timaeus

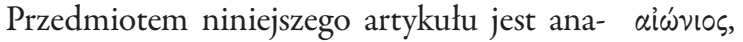

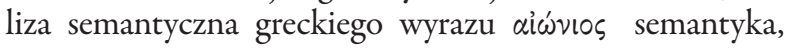
w literaturze helleńskiej od jej początków do czasów powstawania Nowego Testamen-

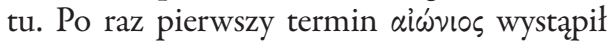
w Państwie Platona, zaś po Platonie był używany przez helleńskich filozofów, poetów i historyków. Cześć pierwsza artykułu przedstawia etymologię ai $\omega$ vios, część druga - analizę semantyczną tego wyrazu w dialogach Platona, część trzecia - jego znaczenie w filozofii po Platonie, część czwarta - w poezji hellenistycznej, część piąta - w historiografii hellenistycznej. Część szósta zawiera przegląd haseł leksykonów bizantyńskich, w których wystąpił wyraz ai $\omega$ vios. Analiza semantyczna użycia aí́vios w literaturze helleńskiej (IV wiek p.n.e. - I wiek n.e.) prowadzi do wniosku, że termin ten w żadnym kontekście 
nie oznacza czegoś, co jest naprawdę wieczne, tj. bez początku i końca, lecz coś innego: długowieczne, długotrwałe, wiecznotrwałe, nieustanne, niekończące się, nieprzerwane, wieczyste, niezniszczalne, niezmienne. $\mathrm{Na}$ 60 wystąpień zaledwie osiem odnosi się do eschatologicznych kar w Hadesie, zaś trzy kolejne dotyczą eschatologicznych nagród. W żadnym z nich nie chodzi o kary czy nagrody, które byłyby faktycznie bez końca, lecz raczej o takie, które będą długotrwałe.

A subject of this article is the semantic analysis of the Greek word aíwvios in Hellenic literature from its beginning to the composition of the New Testament. For the first time, the word ai'́vios occurred in Plato's Republic, and after Plato the term was re-used by the ancient Greek philosophers, poets, and historians. Part one of the paper shows the etymol-

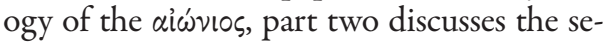
mantics of the word in Plato's dialogues, part three - its meaning in the post-Platonic philosophy, part four - in the Hellenistic poetry, part five - in the Hellenistic historiography. Part six contains an overview of entries in the

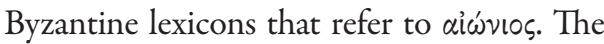
semantic analysis of the aíwvios usus in the ancient Greek literature $\left(4^{\text {th }} \mathrm{c}\right.$. BCE $-1^{\text {st }} \mathrm{c}$. CE) leads to the conclusion that the term in any given context does not denote what is really eternal, i.e. without beginning or end, but something else: longeval, long-lasting, perennial, perpetual, endless, unceasing, imperishable, immutable. Among 60 occurrences only eight refer to eschatological punishments in Hades and three different concern eschato-
KEYWORDS

aí́vios, semantics, ancient Greek literature, Classical period (510-323 BCE), Hellenistic period (323-31 BCE). 
logical rewards. None of them is about punishments or rewards that would be actually endless, but rather the long-lasting ones.

\section{ETYMOLOGIA WYRAZU AISNIOE}

Termin aí่vios wszedł do literatury starogreckiej stosunkowo późno. Po raz pierwszy wystąpił u Platona. Odnotowywane przez opracowania wcześniejsze wystąpienia - we fragmentach pitagorejczyka Ocellusa (VI wiek p.n.e.) $)^{1}$, presokratyka Heraklita z Efezu $(f .504-501 \text { p.n.e. })^{2}$ i historyka Ktezjasza z Knidos $(f l .405 \text { rok p.n.e. })^{3}$ - wypada zakwestionować $\mathrm{z}$ uwagi na to, że żaden $\mathrm{z}$ tych wczesnych autorów nie użył wyrazu aí́vios, a wprowadzili je dopiero późnoantyczni pisarze, którzy ich parafrazują bądź komentują w swoich własnych pismach.

Przymiotnik ai $\omega$ vios pochodzi od archaicznego rzeczownika $\alpha i \omega ́ v$, który z kolei wywodzi się z jeszcze dawniejszego

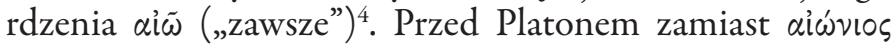

1 „Trójka pierwsza stworzyła początek, środek i koniec” (Ocellus Luca-

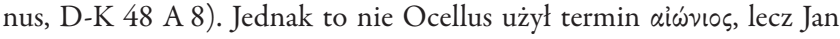
z Lidii w swoim komentarzu do tego zdania mówi o wiecznej wojnie

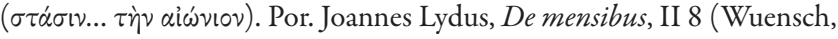
Ioannis, 27). Wszystkie przekłady w niniejszym artykule, o ile nie zaznaczono inaczej, pochodzą od autorki artykułu.

2 „Wszystkim kieruje błyskawica” (Heraclitus Ephesius, D-K 22 B 64). Dyskutowany termin nie został użyty przez samego Heraklita, lecz przez cytującego go Pseudo-Hipolita, który zdefiniował heraklitejską błyska-

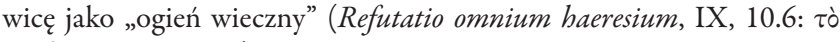

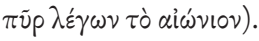

3 Ctesias Cnidius, FGrHist 699 F *45m, w: Claudius Aelianus, De natura animalium, IV, 41 - fragment atetyzowany przez wydawcę, Feliksa Jacoby'ego.

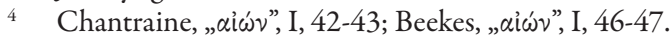


stosowano jońsko-attycki przymiotnik äiઈıs - derywat jońskiego przysłówka aiદí („zawsze”), który także został

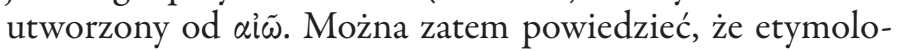

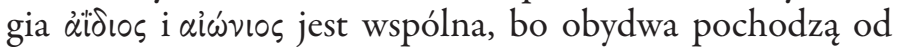
"zawsze". Żaden z tych dwóch przymiotników nie pojawił się w najwcześniejszej literaturze Greków, tj. w poematach

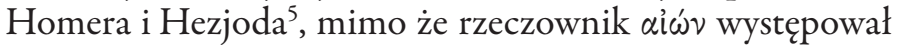

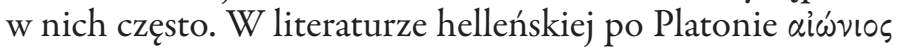
przyjął się, nie wypierając swego starszego synonimu àitoıs. Przeważnie znajdujemy obydwa te wyrazy występujące obok siebie lub zamiennie u autorów uwzględnionych w niniejszym artykule.

$\mathrm{Na}$ temat semantyki tych wyrazów opublikowano co najmniej trzy monografie naukowe. Pierwsze z tych opracowań - doktorat Heleny Keizer ${ }^{6}$ - stanowi studium na temat znaczenia $\alpha i \omega ́ \nu$ w literaturze helleńskiej, grecko-żydowskiej

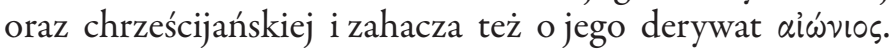
Drugie - książka autorstwa Ilarii Ramelli i Davida Konsta-

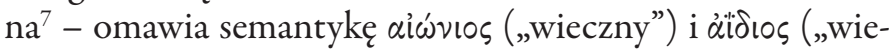
kuisty”) w całej literaturze greckiej od jej początku do Ojców Kościoła włącznie. Trzecie - książka Árpáda Orbána - jest poświęcone pojęciu „świat” u autorów wczesnochrześcijań-

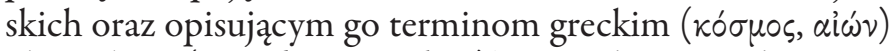
i łacińskim (mundus, saeculum) ${ }^{8}$. Ponadto wypada wspomnieć o opracowaniach cząstkowych dotyczących określeń wieczności w platońskim Timajosie, które znacznie lepiej niż monografia autorstwa Ilarii Ramelli i Davida Konstana analizują termin aí́vııs u Platona9.

Żadna z wyżej wymienionych monografii nie poświęca

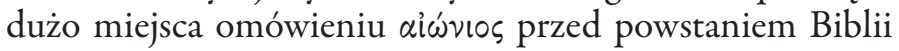

5 Przymiotnik äiồ występuje jeden raz w przypisywanej Hezjodowi $\operatorname{Tarczy}$ (w. 301).

6 Keizer, Life Time Entirety.

7 Ramelli - Konstan, Terms for Eternity.

8 Orbán, Les dénominations du monde.

9 Mohr, „Plato on Time and Eternity”; Mason, „Why Does Plato Believe”. 
greckiej lub niezależnie od niej ${ }^{10}$. Niniejszy artykuł ma za zadanie rzucić więcej światła na kulisy wprowadzenia aí́vios do literatury klasycznej przez Platona, użycie tego słowa u następnych autorów hellenistycznych (filozofów, poetów, historyków), niuansowanie znaczenia i wreszcie definiowanie w bizantyńskich leksykonach.

\section{Aisnios w dialogach Platona (387-347 P.N.e.)}

Termin ai $\omega v$ vios został wprowadzony do literatury greckiej przez Platona ${ }^{11}$.

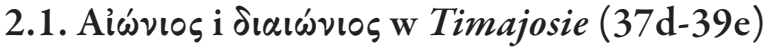

Aí́vios występuje dwukrotnie w Timajosie (37c-39e) - tam gdzie jest mowa o stworzeniu, czasie i wieczności - obok dwóch innych bliskoznacznych przymiotników: äiloıs i $\delta \iota \iota \iota \omega ́ v ı$ s. Ten ostatni, utworzony ze złożenia przyimka

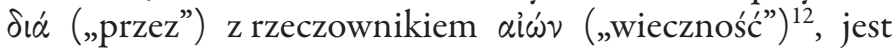
neologizmem ukutym przez Platona i używanym wyłącznie w Timajosie. Platon więc w jednym miejscu użył aż trzech

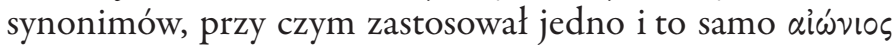
do opisania dwóch różnych konstruktów.

Pierwszym z nich jest model wszechświata - paradygmat

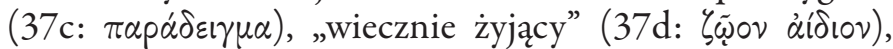
którego natura też jest „wieczna” (37d: aí́vios). Na wzór i podobieństwo owego paradygmatu platoński demiurg „wymyślił pewien ruchomy obraz wieczności” (37d: cikì $\delta$ "

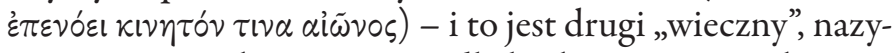
wany również „biegnącym wedle liczby wiecznym obrazem

10 Ramelli - Konstan, Terms for Eternity, 5-35; Keizer, Life Time Entirety, 44-55; Orbán, Les dénominations du monde, 146-147.

11 Ramelli - Konstan, Terms for Eternity, 13 nota 10; Mason, „Why Does Plato Believe”, 178.

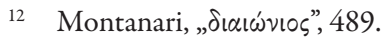




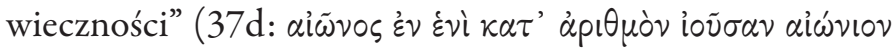
Eikóva). Tym wiecznym obrazem okazuje się być „czas”

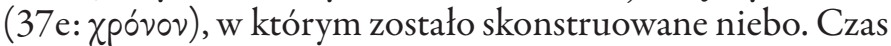

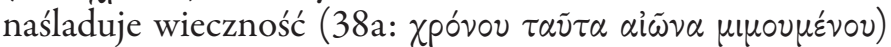

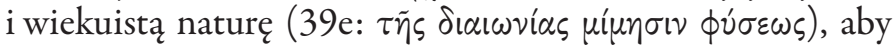
być jak najpodobniejszy do niej (38b-c), a więc nie jest identyczny $\mathrm{z}$ „paradygmatem wiekuistej natury” (38b: $\tau$ ò

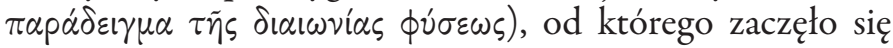
opowiadanie. Różnica między nimi polega na tym, że pa-

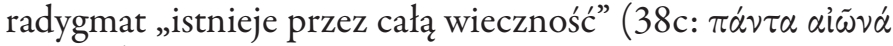
$\dot{\varepsilon} \sigma \tau \iota \nu ้ \nu)$, podczas gdy stworzony wraz z czasem firmament

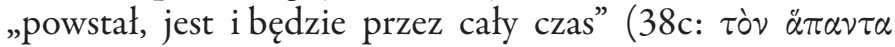

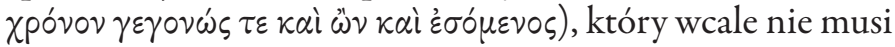
być wieczny, skoro autor dopuszcza możliwość rozpadu nieba i końca czasu (38b).

Platon wyjaśnia różnicę między pojedynczym „jest” a złożonym „był, jest i będzie”. „Po prostu jest” (38a: $\tau$ ¿̀

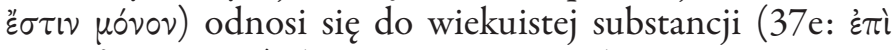

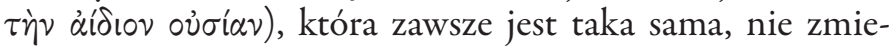

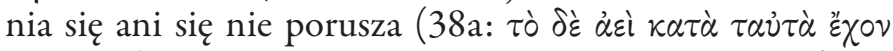
$\dot{\alpha} \kappa เ \nu \dot{\tau} \tau \omega \varsigma)$, nie podlega starzeniu się ani młodnieniu (38a:

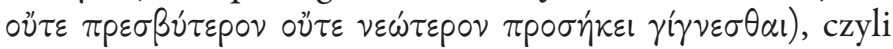

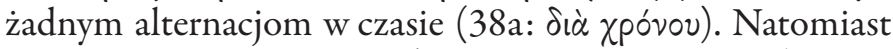

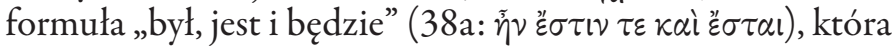
oznacza przeszłość, teraźniejszość i przyszłość, stosuje się do ruchu i ewolucji, a te nie mogą się odbywać inaczej niż tylko w czasie. Zatem wieczność „jest” poza czasem.

Tekst ten przysparza sporo trudności interpretacyjnych. Po pierwsze, nasuwa się pytanie, dlaczego Platon zastosował jeden i ten sam przymiotnik aíwvıs do opisania zarówno paradygmatu, jak i czasu. Richard Mohr starał się wyjaśnić tę trudność filologiczną w taki sposób, że Platon w Timajosie pojmował czas nie jako przemijanie, lecz coś w rodzaju kosmicznego zegara, swoisty standard i model nieba, który dzięki swemu podobieństwu do paradygmatu byłby prawie 
wieczny ${ }^{13}$. To wyjaśnienie nie spotkało się z pełną akceptacją Andrew Masona, który zwrócił uwagę na intertekstualność dialogów Timajosa (37e-38a) i Parmenidesa (141d-e, 151e-152a) oraz na nieuwzględniony przez Mohra - a mocno podkreślany przez Platona - aspekt wieczności i czasowości, jakim jest niezmienność charakterystyczna dla wieczności i zmienność nieodłączna od czasowości. Skoro paradygmat jest niezmienny, musi być też pozaczasowy, i na odwrót, świat, który trwa w czasie, może być wiecznotrwały, ale nie wieczny, a więc $\alpha i \omega ́ v$ เos za każdym razem oznacza coś innego. Mason usiłował wyjaśnić tę niekompatybilność terminu „wieczny” przez przyznanie istniejącemu w czasie światu cechy trwałości - niepodleganie powstawaniu i ginięciu - która jest odbiciem niezmienności ${ }^{14}$.

\subsection{Aí́vios w Prawach (904a)}

W Prawach (904a) Platon rozróżnia między aí́vios i $\alpha \dot{\alpha} \omega \dot{\lambda} \varepsilon \theta$ pos. Bogowie są wieczni, podczas gdy dusza i cia-

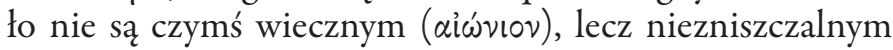
( $\alpha \nu \omega \dot{\lambda} \varepsilon \theta \rho \circ \nu)$, dlatego że dusza, która nie umiera nigdy, wchodzi w kolejne ciała dzięki ich śmiertelności. Bo gdyby nie umierało żadne $\mathrm{z}$ tych dwojga ( $\mathrm{tj}$. ani dusza, ani ciało), nie byłyby w ogóle możliwe narodziny istot żywych ${ }^{15}$. W innych miejscach u Platona ả $\nu \omega \dot{\lambda} \varepsilon \theta$ pos występuje ściśle złączone z $\dot{\alpha} \theta \dot{\alpha} v \alpha \tau o \zeta$ („nieśmiertelny”), przy czym obydwa odnoszą do duszy ${ }^{16}$.

13 Mohr, „Plato on Time and Eternity”, 39-46.

14 Mason, „Why Does Plato Believe”, 177-188.

15 To miejsce jest niejasne, zob. Keizer, Life Time Entirety, 63. Koniekturalny przekład brzmi tak: „Dusza i ciało są czymś niezniszczalnym, lecz przecież nie są wieczne, tak jak wedle prawa bogowie, dlatego że narodziny istot żywych nie byłyby możliwe, gdyby jedno z nich nie ginęło". Por. Plato, Respublica, 608d: „dusza jest nieśmiertelna i nigdy nie ginie”.

16 Ramelli - Konstan, Terms for Eternity, 15. 
Co to znaczy, że dusza wprawdzie jest nieśmiertelna, lecz jednak nie jest tak jak bogowie wieczna? Ilaria Ramelli i David Konstan interpretują tę zagadkę językową w ten sposób, że à $\nu \omega ́ \lambda \varepsilon \theta p o \varsigma$ odnosi się do czegoś, co nie ma końca, choć miało początek, podczas gdy aí́vios oznacza coś istniejącego odwiecznie, bez początku ${ }^{17}$. Moim zdaniem myśl Platona jest inna, mianowicie taka, że bogowie są wieczni w takim samym sensie jak wszechświat: bo byli, są i będą, trwając dzięki temu, że ich ciała są na zawsze zrośnięte z duszami (por. Platon, Fajdros, 246c). Wprawdzie nie istnieją odwiecznie, niemniej jednak można ich uważać za

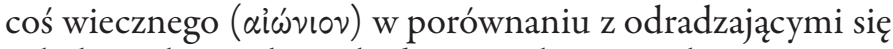
w kolejnych wcieleniach duszami, które - choć są czymś niezniszczalnym ( $\alpha \omega \omega \dot{\nu} \lambda \varepsilon \theta \rho \nu)$ - to jednak podlegają narodzinom i śmierci.

\subsection{Aí́vios w Państwie (363d)}

W Państwie (363c-d) Platon parafrazuje słowa dawnych poetów: Muzajosa i jego syna, którzy utrzymywali, że sprawiedliwi po śmierci otrzymują od bogów nagrodę taką, że w Hadesie mogą przez cały czas ucztować w wieńcach na głowach i z kielichami wina w rękach. Jakby poeci ci wierzyli, dodaje Platon, że najpiękniejszą zapłatą za cnotę jest

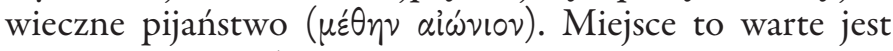
przytoczenia w całości:

Jeszcze większe od tamtych (sc. Hezjoda i Homera) nagrody od bogów dają sprawiedliwym Muzajos i jego syn. Za pomocą słowa sprowadzają sprawiedliwych do Hadesu, sadzają przy stole i zastawiają przed nimi ucztę pobożnych. Przedstawiają ich jako uwieńczonych i przez cały już czas pijanych, sądząc widocznie, że najpiękniejszą nagrodą za cnotę jest nieustanne pijaństwo.

17 Ramelli - Konstan, Terms for Eternity, 12-13. 
Trudno przypuszczać, że Platon w tym miejscu - mimo że przytacza cudze poglądy, z którymi się nie zgadza - użył

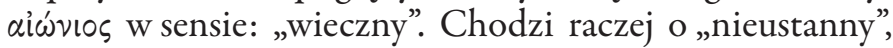
„notoryczny”, „niekończący się”. Dlatego że według podobnych podań eschatologicznych przytaczanych w tym samym dialogu (Państwo 615a) dusza w zaświatach przebywa długo, lecz czasowo - dokładnie przez 1000 lat - po czym wstępuje w kolejne ciało. Jest więc bardziej prawdopodobne, że założyciel Akademii użył sformułowanie $\mu \varepsilon \dot{\theta} \eta \eta$

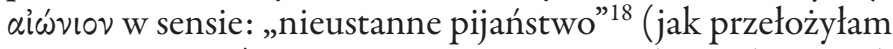
powyższy cytat), a nie „pijaństwo na wieki wieków”, jak przetłumaczył Władysław Witwicki.

W cytowanym miejscu Platon powołuje się na poetę Muzajosa i jego syna, którego Plutarch z Cheronei identyfikował z „Orfeuszem”"19, niżej zaś (Panstwo 364e) mówi o „stertach ksiąg” Muzajosa - syna Księżyca i Orfeusza syna Muzy. Księgi te, dostępne w czasach Platona, zaginęły pod koniec starożytności. Zachowały się z nich jedynie fragmenty, między innymi omówione wyżej miejsce ${ }^{20}$. Platon jest jednym z najwcześniejszych autorów, który zacytował rzeczonych poetów. Trudno datować ich poematy. Ogólnie rzecz ujmując, wypada umieścić poezję Pseudo-Muzajosa i Pseudo-Orfeusza między Homerem, który ich nie zna, a Pindarem, który ich cytuje jako pierwszy, i datować na początek okresu klasycznego, tj. między 510 rokiem p.n.e. a 460 rokiem p.n.e. ${ }^{21}$.

Niestety nie można zajrzeć do oryginalnych utworów wspomnianych przez Platona poetów, żeby sprawdzić, czy

18 Ramelli - Konstan, Terms for Eternity, 12.

19 Plutarchus Chaeronensis, Comparatio Cimonis et Luculli, I, 2.

20 W najnowszej edycji fragmentów orfickich sporządzonych przez Alberto Bernabé wskazane miejsca otrzymały następującą atrybucję: Plato, Respublica, 363d + Plutarchus Chaeronensis, Comparatio Cimonis et Luculli, I, 2 = Pseudo-Orpheus, De animae natura, origine et fato, PEG, II/1, fr. 431; Musaeus, De animae natura, origine, fato, PEG, II/3, fr. 76.

21 Zarewicz, Przywotywanie bogów, 175-191. 
któryś z nich użył aí่vios. Wobec braku starszych tekstów źródłowych niż Platon pozostaje skonsultować Hymny orfickie. Jest to zbiór 87 hymnów kultowych niewiadomego autorstwa i niepewnej datacji (okres klasyczny, hellenistyczny lub rzymski), których treść dowodzi bardzo dobrej znajomości tradycji orfickiej i związku z misteriami orfickimi.

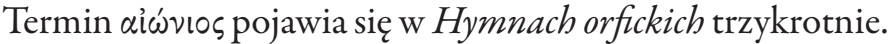

Godne szczególnej uwagi są dwa użycia: w hymnie do Heliosa i w hymnie do Hefajstosa. Pierwszy z wymienionych utworów przywołuje Heliosa-Słońce epitetem „ma-

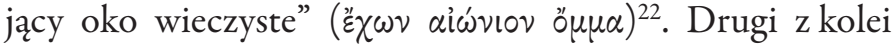
opisuje Hefajstosa - ogień kosmiczny identyczny ze Słoń-

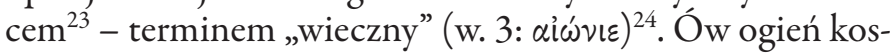
miczny płonie, jak czytamy dalej (w. 6), w eterze, słońcu, gwiazdach, księżycu - słowem we wszystkich ciałach niebieskich. To użycie przypomina miejsce z Timajosa (37d) o czasie - „wiecznym obrazie wieczności”, który powstał wraz z niebem, by odmierzać jego trwanie. Trzecie i ostatnie w Hymnach orfickich użycie pojawia się w hymnie do Śmier-

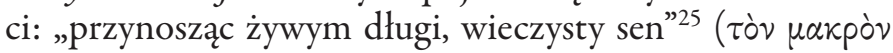

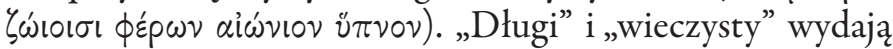

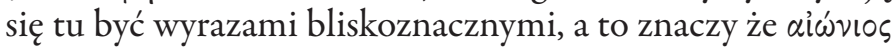
na pewno nie zostało użyte w sensie „wieczny”, lecz raczej zgodnie z polską frazeologią - w znaczeniu „wieczysty”.

\subsection{Podsumowanie}

Aî́vios występuje czterokrotnie w trzech późniejszych dialogach Platona: dwukrotnie w Timajosie (w odniesieniu do

22 Hymni Orphici, VIII, 1 (Fayant, Hymnes orphiques, 81; Żybert, Hymny orfickie, 64).

23 Fayant, Hymnes orphiques, 84 nota do V.1.

24 Hymni Orphici, LXVI, 3 (Fayant, Hymnes orphiques, 535; Żybert, Hymny orfickie, 97).

25 Hymni Orphici, LXXXVII, 5 (Fayant, Hymnes orphiques, 665; Żybert, Hymny orfickie, 107). 
paradygmatu i do czasu) oraz po jednym razie w Prawach (w odniesieniu do bogów) i w Państwie (w związku z eschatologicznymi nagrodami obiecywanymi w misteriach orfickich). Kontekst wystąpienia aí́vios w Państwie wydaje się wskazywać, że Platon zapożyczył ten termin z ezoterycznych poezji Muzajosa i Orfeusza, które w jego czasach były już spisane. W tych wersetach - wedle naszej skromnej wiedzy o nich - aíwvios odnosiło się do czegoś wiecznotrwałego, jak Słońce, lecz jednak nie wiecznego. Dwa wystąpienia w Timajosie wydają są na pierwszy rzut oka niekompatybilne lub niekonsekwentne, dlatego że aí́vios raz odnosi się do paradygmatu, który jest wieczny w sensie absolutnym, a raz do czasu, który był, jest i będzie tak długo jak wszechświat, wraz z którym został stworzony. W Prawach bogowie są zdefiniowani

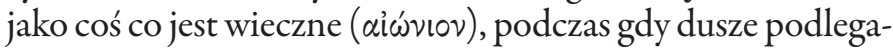
jące cyklicznej inkarnacji są nazwane czymś nieśmiertelnym, ale nie wiecznym. Wydaje się, że wspólnym mianownikiem dla znaczenia aísvios w odniesieniu do czasu, wszechświata i bogów jest ich trwałość, stabilność, niezmienność, to znaczy niepodleganie cyklowi powstawania i ginięcia, któremu z konieczności podlegają dusze ludzkie. Gdy więc Platon mówi aí́vios, ma na myśli „niezmienny”, a z kolei dwa podobne wy-

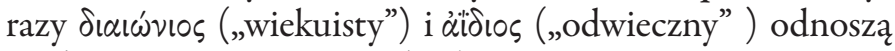
się do wieczności w sensie absolutnym.

\section{Aisnios w filozofit po Platonie (305 ROK P.N.E. -100 ROK N.E.)}

Stan zachowania tekstów filozoficznych z okresu hellenistycznego jest szczątkowy, wobec czego poniższe wnioski mają charakter koniekturalny. Na przykład trudno orzec, czy filozofowie Akademii Platońskiej po Platonie

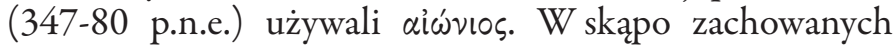
fragmentach wyraz ten występuje jedynie u scholarchy Ksenokratesa (fl. $339-314$ p.n.e.) w odniesieniu do świata 
i atomów, które w myśl jego doktryny były wieczne w sen-

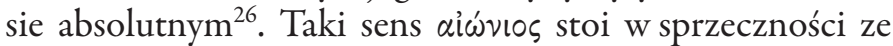
wszystkim innym, co wiemy na temat użycia tego terminu w filozofii hellenistycznej. Nasuwa się więc pytanie, czy Ksenokrates był aż tak ekscentryczny w stosowaniu terminologii filozoficznej, czy też może to użycie pochodzi od Sekstusa Empiryka ( fl. 200 n.e.), który go cytuje. Na podstawie dostępnego materiału zakładamy, że akademicy nie stosowali tego terminu, a wyjątkowe użycie u Ksenokratesa pochodzi od Sekstusa Empiryka. Ale czy na pewno? Tego oczywiście nie wiemy.

\subsection{Aí́vios w epikureizmie (305-40 p.n.e.)}

Część pism Epikura ( $f .305-270$ p.n.e.) zachowała się w późniejszej tradycji epikurejskiej. Mimo że transmisja tych tekstów jest długa, nie zniekształciła jego słów, dlatego że epikurejczycy aż do końca istnienia Ogrodu Epikura (czyli do 267 roku n.e.) dochowywali wierności doktrynie mistrza.

Epikur rozróżniał między wiecznością a długowiecznością. Według jego nauki atomy i próżnia są wieczne w sensie absolutnym („odwieczny”, „bez początku i bez końca”) i jako takie zwykły być opisywane przymiotnikiem ḋïd $10 \varsigma^{27}$. „Proces ten (sc. zderzenia atomów) nie ma początku, ponieważ atomy i próżnia są odwieczne (äïßı৩)", pisał Epikur ${ }^{28}$. Podobnie rzymski epikurejczyk Filodemos z Gadary ( $f$. 70-40 p.n.e.) w odniesieniu do wieczności bogów używał przymiotników ¿̇iò

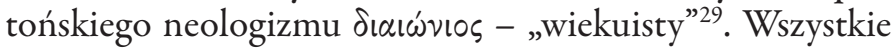
trzy użyte przez Filodemosa określenia są synonimami, a ich

26 Xenocrates Chalcedonius, fr. F 43 Isnardi Parente (Isnardi Parente, Senocrate, 120).

27 Ramelli - Konstan, Terms for Eternity, 34.

28 Epicurus, Epistula ad Herodotum, 44 (Arrighetti, Epicuro, 41; Krońska, Diogenes Laertios, 606).

29 Philodemus Gadarensis, De pietate, 46, 69 (Obbink, Philodemus, 109, 111). 
użycie w odniesieniu do wieczności absolutnej pochodziło od samego Epikura ${ }^{30}$.

Aí́vvı systąpiło u Epikura w jeszcze innym kontekście. Ból to coś, co z punktu widzenia indywidualnego człowieka wydaje się nie mieć końca, podczas gdy faktycznie „[...] cierpienie nie jest wieczne (aísvıv) ani nawet bardzo długie

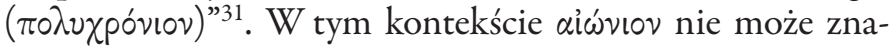
czyć „wieczne”, bo nie jest wieczne życie ludzkie, podczas którego człowiek cierpi. Sens jest taki, że ktoś, kto bardzo cierpi, wyobraża sobie, że jego ból będzie trwać do końca życia. Ta-

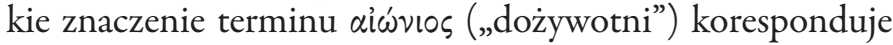
z kolokwialnym użyciem wyrazu w późniejszej grece, gdzie

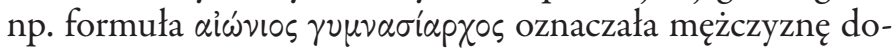
żywotnio pełniącego urząd przełożonego gimnazjonu ${ }^{32}$.

Założyciel Ogrodu zwalczał mity o karach w Hadesie. Jego zdaniem ludzi przejmowała lękiem zwłaszcza długość tej mitycznej kary, która miała być rzekomo „jakimś wiecz-

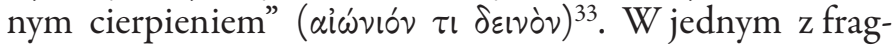
mentów zachowanych w papirusie Filodemosa z Herkulanum (P.Herc. 1056) Epikur domaga się ustalenia jasnego kryterium prawdy, które pozwoli ocenić, czy spodziewane szczęście albo dyskomfort rzekomo czekające duszę w zaświatach mają być wieczne, czy też - na odwrót - nie

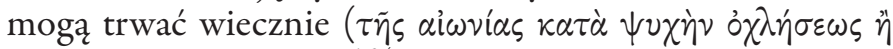

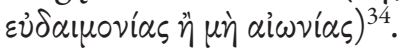

30 Ramelli - Konstan, Terms for Eternity, 35.

31 Epicurus, Ratae sententiae, XXVIII (Arrighetti, Epicuro, 131).

32 LSJ, „aí่vios 2", 45.

33 Epicurus, Epistula ad Herodotum, 81 (Arrighetti, Epicuro, 71; Krońska, Diogenes Laertios, 623). Por. Philodemus Gadarensis, De pietate, 2235-2236 (Obbink, Philodemus, 258, komentarz: 590): „Ludzie są często przekonani, że bogowie w zaświatach będą ich prześladować wiecz-

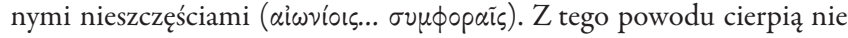
mniej niż gdyby naprawdę ich prześladowali".

34 Epicurus, Incertus liber, fr. 31.32, vv. 4-5 (Arrighetti, Epicuro, 352). Zob. Ramelli - Konstan, Terms for Eternity, 34-35. 
Epikur nie podał, kto w jego czasach rozpowszechniał tego rodzaju mity eschatologiczne, natomiast jeden z jego następców - Kolotes z Lampsaku (fl. 285-265 p.n.e.) - napisał krytykę mitu Era z ostatniej księgi Państwa ${ }^{35}$, gdzie Platon mówi (616a) o odbywanych w Tartarze karach, które są nie dłuższe niż 1000 lat, tj. czas spędzany przez dusze w zaświatach między kolejnymi wcieleniami. Epikur zatem odnosił się do eschatologicznych mitów Platona.

\subsection{Aí́vlos w stoicyzmie (ok. $250-50$ p.n.e.)}

Wedle naszych najlepszych źródeł rzeczownik aiı́v i przymiotnik ai $\omega$ vios były stosowane przez filozofów ze szkoły stoickiej. Warron (116-27 p.n.e.) przytacza etymologię

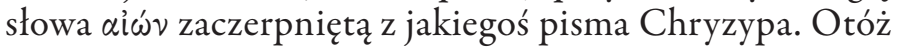
Chryzyp, jak podaje Warron, twierdził, że grecki wyraz

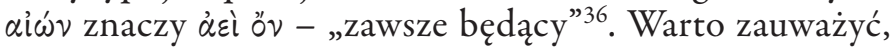
że samo wyrażenie $\dot{\alpha} \varepsilon \dot{~ o ै v ~(l u b ~} \dot{\alpha} \varepsilon \grave{\omega} \omega ै \nu)$ występuje w platońskim Timajosie (28a, 34a, 37a) w odniesieniu do wieczności idei i demiurga ${ }^{37}$.

Szczegółowa analiza szeregu fragmentów Chryzypa z Soloi (ok. 279-206 p.n.e.) oraz innego stoika Posidoniusza z Apamei (ok. $135-51$ p.n.e.) ${ }^{38}$ przedstawiona przez Ilarię Ramelli i Davida Konstana prowadzi do konstatacji, że stoicy rozgraniczali semantykę dwóch pojęć: àiồ Pierwszy z nich był zastrzeżony dla wieczności w sensie metafizycznym, np. wieczności Boga albo wieczności materii, która wedle stoików istnieje odwiecznie; natomiast drugie - aí́vios - odnosiło się do każdego kolejnego cyklu kosmicznego ( $\left.\alpha i \omega^{\prime} v\right)$, bo wedle doktryny Chryzypa świat, choć

35 Porphyrius Tyrius, In Platonis rem publicam commentarii, fr. $182 \mathrm{~F}$ (Smith, Porphyrii, 207-212).

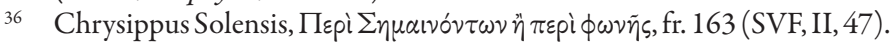
Por. Keizer, Life Time Entirety, 92.

37 Mason, „Why Does Plato Believe”, 178.

38 Ramelli - Konstan, Terms for Eternity, 30-34. 
wieczny, rozpadał się na szereg cykli kosmicznych, które miały określony czas trwania (Chryzyp nie podał konkretnych liczb), czyli nie były wieczne.

Takie użycie sugeruje jeden fragment Chryzypa oraz trzy fragmenty Posidoniusza, w których aíwvıos odnosi się do

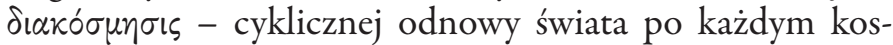
micznym pożarze ${ }^{39}, \pi \dot{x} \theta$ os - powtarzającego się regularnie

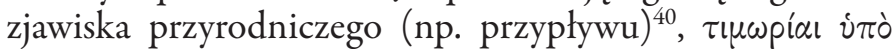
$\gamma \tilde{\eta} \nu$ - kar dla grzeszników w zaświatach ${ }^{41}$, oraz $\delta o^{\xi} \xi \alpha-l u d z-$ kiej sławy ${ }^{42}$. W ostatnim z fragmentów Posidoniusz - zdaniem Ilarii Ramelli i Davida Konstana ${ }^{43}$ - zacytował Diodora Sycylijskiego (Biblioteka historyczna, XXXVII, 4.1), który pisze o „wiecznej chwale”.

Żadne z tych wystąpień - niestety ich fragmentaryczność uniemożliwia dogłębniejszą analizę - nie wskazuje na wieczność w pełnym tego słowa znaczeniu, lecz raczej na coś w sensie: „długotrwały”, „nieustanny”, „kontynuowany”, „powtarzalny”, „cykliczny”. Nawet eschatologiczna kara nie mogła być wedle Posidoniusza naprawdę wieczna, dlatego że stoicy, poczynając od Chryzypa, wierzyli w cykliczny po-

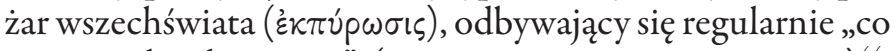

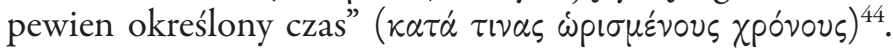
A przecież kosmiczny pożar musiałby położyć kres również owym „karom pod ziemią".

39 Chrysippus Solensis, De mundo, fr. 597 (SVF, II, 184).

40 Posidonius Apameus, De Oceano, fr. 44a (Theiler, Posidonios, I, 59).

41 Posidonius Apameus, Moralia, fr. 441e (Theiler, Posidonios, I, 356).

42 Posidonius Apameus, Historiae (Historia post Polybium), fr. 212 (Theiler, Posidonios, I, 167).

43 Ramelli - Konstan, Terms for Eternity, 31. Na ogół przyjmuje się, że Diodor zależy od nieco wcześniejszego Posidoniusza, a nie odwrotnie. Zob. np. Wozniczka, „Diodoros' Narrative”.

44 Chrysippus Solensis, De mundo, fr. 606 (SVF, II, 186); ibidem, fr. 610 (SVF, II, 186). 


\subsection{Aí́vlos w neopitagoreizmie (80 rok p.n.e. -100 rok n.e.)}

Ze względu na słaby stan zachowania pism pitagorejskich trudno oszacować, jak często występował w nich termin aí́vios. W zbiorze tekstów pitagorejskich z epoki helleni-

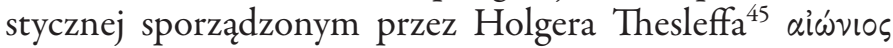
pojawia się zaledwie czterokrotnie. $Z$ tych wystąpień należy od razu odrzucić dwa: jedno u Ocellusa ${ }^{46}$ i jedno u Filolao$\mathrm{sa}^{47}$, ponieważ aí́vios został użyty nie przez nich samych, lecz przez późniejszych autorów, którzy ich cytują: Jana z Lidii (540 rok n.e.) i Jamblicha z Chalkis (fl. 280-300 n.e. $)^{48}$. Pozostałe dwa występują w piśmie Timajosa z Lokri O naturze świata $i$ duszy.

Autentyczność tego pisma budzi jednak poważne wątpliwości. Obecnie uważa się, że utwór został napisany nie przez pitagorejczyka Timajosa ( $\mathrm{V}$ wiek p.n.e.), którego imieniem Platon zatytułował jeden ze swoich dialogów, lecz raczej przez jakiegoś medioplatonika z hellenistycznej Aleksandrii (80 rok p.n.e. - 100 rok n.e.), który władał dialektem pseudo-doryckim ${ }^{49}$ - w tym bowiem dialekcie został napisany utwór ${ }^{50}$. Pierwszymi, którzy zacytowali Pseudo-Timajosa, byli medioplatonicy Nikomach z Gerazy ( $f$. 100 rok n.e.) i Kalwenus Taurus ( $f$. 145 rok n.e.), zaś sam Pseudo-Timajos dobrze znał pisma Filona Aleksandryjskiego (ok. 25 rok p.n.e. -50 rok n.e.) i oczywiście treść platońskiego Timajosa.

\footnotetext{
45 Thesleff, The Pythagorean.

46 Zob. wyżej przypis 1.

47 Philolaus, D-K, 44 B 23.

48 Ramelli - Konstan, Terms for Eternity, 7, 10.

49 Dialekt pseudo-dorycki - dialekt koinē okraszony doryckimi formami

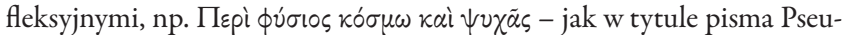
do-Timajosa. Dialekt pseudo-dorycki był zasadniczo różny od dialektu doryckiego, którym mówili Grecy w Italii i na Sycylii w epoce klasycznej.

50 Tobin, Timaios of Locri, 3-7.
} 
Pseudo-Timajos używa aí́vıos w dwu kluczowych miejscach swego pisma ${ }^{51}$. W pierwszym miejscu, na początku utworu, stosuje ten przymiotnik jako epitet Boga $(\Theta \varepsilon \dot{\partial} v \delta \grave{\varepsilon}$

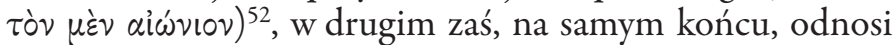
go do idealnego modelu świata, według którego Bóg stwo-

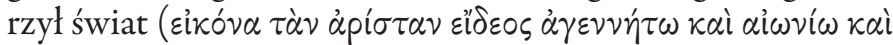
vo $\alpha \tau \tilde{\omega})^{53}$. Twierdzi, że istnieją dwie przyczyny wszechrzeczy: umysł (vóos) i konieczność (à $\alpha \dot{\alpha} \gamma \kappa \alpha)$. Pierwszą z nich identyfikuje z Bogiem, który stworzył świat niewidzialny i na jego wzór powołał do życia świat widzialny. Dowodzi dalej, że w stwarzaniu świata widzialnego Bóg był ograniczany przez drugą przyczynę wszechrzeczy - konieczność, czyli materię i przestrzeń - i że człowiek postrzega za pomocą zmysłów tylko świat widzialny i nie widzi jego stwórcy Boga, czyli Umysłu, który może być poznany jedynie przez kompatybilny z Nim umysł ludzki ${ }^{54}$.

W tym miejscu wywodu stwórca obu światów został na-

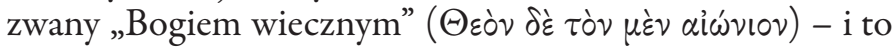
znaczenie: „wieczny” jest tutaj właściwe. Drugim „wiecznym" u Pseudo-Timajosa jest idealny model świata $\left(\pi \circ \tau^{\prime}\right.$

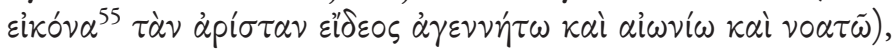
czyli platoński paradygmat, określony przez Platona tym samym przymiotnikiem aí́vios, choć innym rzeczownikiem $\pi \alpha p \alpha ́ \delta \varepsilon 1 \gamma \mu \alpha$. To drugie użycie jest platońskie (por. Timajos, 37d), ale tamto pierwsze wyrażenie, odnoszące się do wiecznego Boga ponad obydwoma światami, jest zupełnie nieplatońskie i nie da się go wyjaśnić inaczej niż wpływem Filona Aleksandryjskiego, który zaczerpnął je z Septuaginty.

51 Keizer, Life Time Entirety, 105-107.

52 Timaeus Locrus, De natura mundi et animae, 24 (Thesleff, The Pythagorean, 213).

53 Timaeus Locrus, De natura mundi et animae, 88 (Thesleff, The Pythagorean, 225).

54 Tobin, Timaios of Locri, 13-15, 75, nota 8.

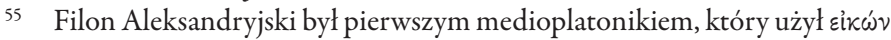
w sensie „paradygmat”, zob. Tobin, Timaios of Locri, 5 . 
Dla porównania podajmy, że współczesny Pseudo-Timajosowi Pseudo-Longinus, autor retorycznego traktatu O wzniostości, stosowat termin aíwvios zgodnie z uzusem platońskim w odniesieniu do homeryckich bogów, których naturę, jak również nieszczęścia, poeta uczynił „wiecznymi”, to znaczy: niezmiennymi, niekończącymi się ${ }^{56}$.

Można jeszcze wspomnieć o tym, że Geminus (I wiek p.n.e. - I wiek n.e.) we Wprowadzeniu do astronomii przypisuje pierwszym pitagorejczykom pogląd o tym, że ciała niebieskie (tj. Słońce, Księżyc i pięć planet) są „boskie

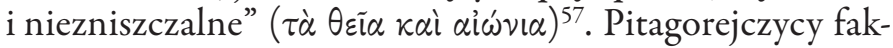
tycznie tak uważali, ale myśl jest sformułowana w taki spo-

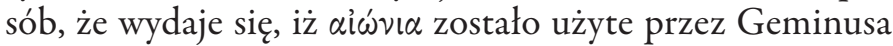
referującego poglądy dawnych pitagorejczyków, a nie przez nich samych.

\subsection{Podsumowanie}

Aíwvıs w filozofii po Platonie nie znaczył „wieczny”, lecz raczej „długotrwały”, „cykliczny”, „trwający do końca świata". W skromnie zachowanych tekstach filozoficznych z okresu hellenistycznego wystąpił cztery razy u epikurejczyków, cztery razy u stoików oraz pięć razy u pitagorejczyków, z czego trzy użycia są wątpliwe (mogą pochodzić od autorów z okresu rzymskiego). Spośród tych dziesięciu wystąpień tylko jedno - u Pseudo-Timajosa ( $O$ naturześsiata i duszy) - odnosi się do absolutnej wieczności Boga. Jednak nawet to pojedyncze użycie jest zapożyczeniem z Filona Aleksandryjskiego.

56 Pseudo-Longinus, De sublimitate, IX, 8 (Podbielski - Narecki, Trzy greckie stylistyki, 103).

57 Geminus, Elementa astronomiae, I, 20 (Manitius, Gemini, 10), por. I, 19. 


\section{AisNios W POEZJI HELLENISTYCZNEJ (III WIEK P.N.E.)}

Poeci hellenistyczni: Kallimach, Likofron, Apolloniusz z Rodos, Moschion, Teokryt i inni często stosowali rzeczow-

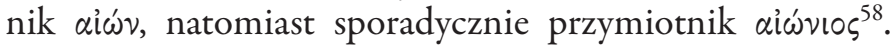
Jedynie Kallimach (310-240 p.n.e.) użył tego wyrazu dwukrotnie w swoich hymnach. W hymnie $\mathrm{Na}$ Artemidę przedstawił boginię antropomorficznie, jako małą dziewczynkę, która siedząc na kolanach ojca Zeusa, prosi go, by pozwolił

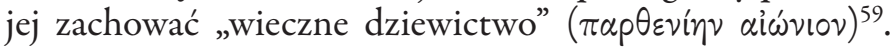

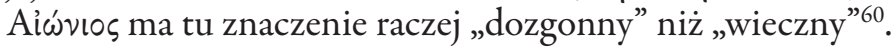
W hymnie $\mathrm{Na}$ Delos poeta kazał rzece Penejos w Tesalii za-

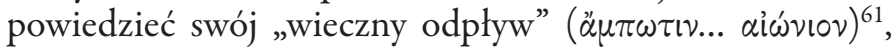

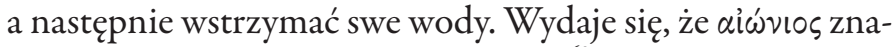
czy tu „nieustanny”, „niekończący się" ${ }^{62}$. Ten zapowiedziany „nieustanny odpływ” trwa zaledwie chwilę, po czym rzeka znów zaczyna płynąć tak jak zwykle ${ }^{63}$. Cyrenejczyk zastosował tu poetycką przesadę lub poetycką ironię.

\section{AISNIOE W HISTORIOGRAFII HELLENISTYCZNEJ (322-8 P.N.E.)}

Pisma historyków z okresu hellenistycznego zachowały się w stanie szczątkowym. Na przykład, z historii Rzymu autorstwa Polibiusza, która oryginalnie liczyła 40 ksiagg (datowane na 160-118 p.n.e.), przetrwało w całości zaledwie pięć, a mimo to jest to jedna z lepiej zachowanych historii tego okresu.

58 Keizer, Life Time Entirety, 44-48.

59 Callimachus, Hymnus III In Dianam, 6 (Pfeiffer, Callimachus, II, 9; Ławińska-Tyszkowska, Kallimach, 138).

60 Keizer, Life Time Entirety, 44 nota 120.

${ }_{61}$ Callimachus, Hymnus IV In Delum, 130 (Pfeiffer, Callimachus, II, 23; Ławińska-Tyszkowska, Kallimach, 168).

62 Keizer, Life Time Entirety, 44 nota 120.

63 Callimachus, Hymnus IV In Delum, 130-150 (Pfeiffer, Callimachus, II, 23; Ławińska-Tyszkowska, Kallimach, 168-169). 


\subsection{Wyrażenie „wieczna pamięć”}

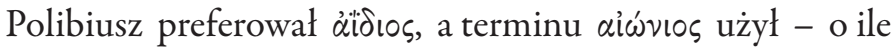
wiadomo - tylko jeden raz. Relacjonując okoliczności śmierci Aratosa z Sykionu (zm. w 213 roku p.n.e.) - przewodniczącego Związku Achajskiego prawdopodobnie otrutego przez Filipa V Macedońskiego - pisze, że Achajowie uchwalili ku jego czci ofiary i kult herosa, czyli to wszystko,

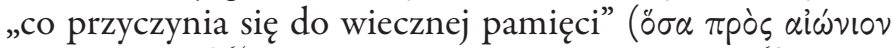

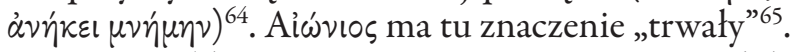

Fraza Polibiusza o „wiecznej pamięci” spodobała się następnym greckim historykom: Diodorowi Sycylijskiemu ( $f$. 60-20 p.n.e.) i Dionizjuszowi z Halikarnasu (fl.30-8 p.n.e.). Historia powszechna Diodora pod tytułem Biblioteka historyczna liczyła oryginalnie $40 \mathrm{ksiąg}$. W zachowanych 15 księgach (księgi 1-5 i 11-20) i pozostałych fragmentach użył on czterokrotnie wyrażenia „wieczna pamięćc6 ${ }^{\prime \prime}$. Doprecyzował tę frazę dodając, że chodzi o wieczną pamięć u wszystkich ludzi i że jest to pamięć o dokonaniach, o cywilizacji i filantropii. W księdze XXXII zaznaczył, że właśnie owa wieczna pamięć była celem przyświecającym mu podczas pisania o nieszczęściach Greków, aby ostrzec przyszle pokolenia przed powtórzeniem ich błędów. Z kolei we wstępie do swego dzieła - w księdze I pięknie pisze o sile historii, rozciągającej się na całą zamieszkałą ziemię, która ma wszystko niszczący czas, jako strażni-

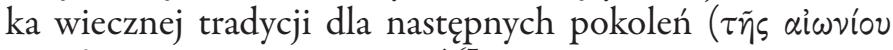

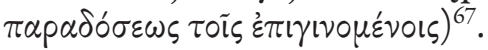

64 Polybius, Historiae, VIII, 12(14).8 (Büttner-Wobst, Polybii, II, 347; Hammer - Brożek, Polibiusz, I, 376).

65 Ramelli - Konstan, Terms for Eternity, 35.

66 Diodorus Siculus, Bibliotheca historica, V, 73.1 (DS, II, 103); XXIII, 16.2 (DS frs., II, 106); XXXII, 27.1 (DS frs., III, 211); XXXVII, 1.1 (DS frs., IV, 194).

67 Diodorus Siculus, Bibliotheca historica, I 2.5 (DS, I, 5). 


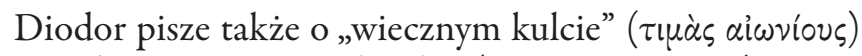

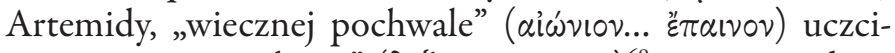

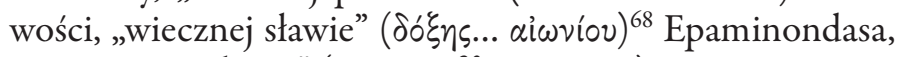
„wiecznej niesławie” ( $\alpha i \omega v i ́$ oı $\beta \lambda \alpha \sigma \phi \eta \mu i \alpha$ is) mającej spaść na

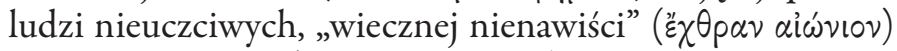

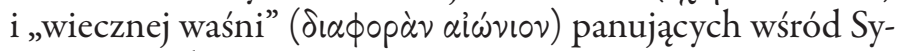
cylijczyków ${ }^{69}$. Wieczna waśń - wyjaśnia - to taka, która jest przekazywana z pokolenia na pokolenie ${ }^{70}$. Aíwvios u Diodora nie znaczy „wieczny”, lecz po prostu „trwały” ${ }^{1}$.

Również Dionizjusz z Halikarnasu zapożyczył z Polibiusza "wieczną pamięć" i zastosował czterokrotnie w Dawnych dziejach Rzymu ${ }^{72}$. Używał także podobnych zwro-

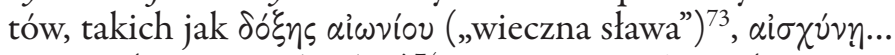

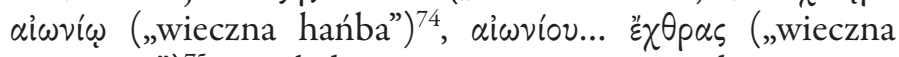
nienawiśćc" $)^{75}$. Wyglądają one na inspiracje Diodorem.

\subsection{Aí́vıเos w sensie ,wiecznotrwały”}

Diodor stosował aí́vios także w odniesieniu do trwałych materiałów budowlanych, tj. kamieni. W opisie kompleksu pałacowego w Persepolis podał, że jeden z murów otaczających pałac był zbudowany z twardego kamienia „na wieczne

68 Gdzie indziej Diodor (Bibliotheca historica, I 56.1) pisze także o „nie-

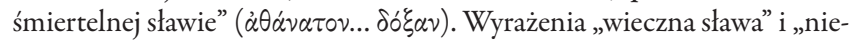
śmiertelna sława" są synonimami, zob. Keizer, Life Time Entirety, 52.

69 Lokalizacja tych wyrażeń u Diodora jest następująca: „wieczny kult”, IV, 51.4 (DS, I, 476); „wieczna pochwała”, XXXII, 30 (DS frs., III, 213); „wieczna sława”, XV, 66.1 (DS, III, 452) i XXXVII, 4.1 (DS frs., IV, 198); „wieczna niesława”, I, 1.5 (DS, I, 3); „wieczna nienawiść”, XIII, 32.3 (DS, III, 49); „wieczna waśń”, XIII, 23.2 (DS, III, 37) i XIII, 24.6 (DS, III, 39).

70 Diodorus Siculus, Bibliotheca historica, XIII, 23.2 (DS, III, 37).

71 Ramelli - Konstan, Terms for Eternity, 31-32.

72 Dionysius Halicarnaseus, Antiquitates Romanae, III, 71.5 (DH, I, 399); IV, 25.3 (DH, II, 45); IV, 40.6 (DH, II, 73); VIII, 55.2 (DH, III, 208).

73 Dionysius Halicarnaseus, Antiquitates Romanae, I, 6.3 (DH, I, 10).

74 Dionysius Halicarnaseus, Antiquitates Romanae, X, 36.5 (DH, IV, 68).

75 Dionysius Halicarnaseus, Antiquitates Romanae, VI, 80.3 (DH, II, 382). 


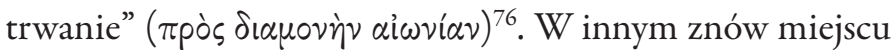
opisał największą z trzech piramid na nekropoli memfickiej (obecnie Giza) jako wzniesioną z bardzo twardego kamienia, trudnego do obróbki, który posiada „wiecznotrwałość"

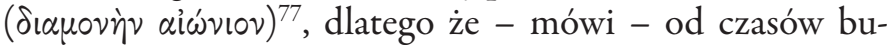
dowy piramidy minęły tysiące lat - może nawet 3400 lat, jak obliczają poniektórzy ${ }^{78}$ - i wbrew upływowi czasu cała konstrukcja trwa nienaruszona. Ostatnie miejsce z Diodora nie jest de facto miejscem z Diodora. Według Feliksa Jacoby'ego Diodor przytoczył w tym miejscu (Biblioteka historyczna, I, 10.1-I 98.10) obszerny ustęp z Hekatajosa ( f. 322-305 p.n.e.). Ten Hekatajos, Grek rodem z Abdery lub Teos, pisał m.in. o Egipcjanach i Żydach. Nie wiadomo z jakiego dzieła Hekatajosa Diodor zaczerpnął ten ekscerpt, być może z historii Egiptu pod tytułem Egyptiaka ${ }^{79}$. W każdym razie słownictwo i poszczególne wyrażenia, w tym

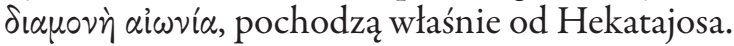

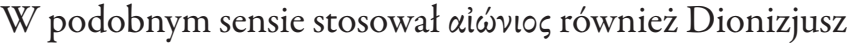
z Halikarnasu w pismach retorycznych:Demostenes i $O$ uktadzie wyrazów. Ten przymiotnik odnosi się do mów politycznych jego ulubionego mówcy - Demostenesa. Mowy

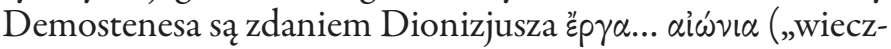
notrwałymi dziełami” $)^{80}$, bo - jak wyjaśnia - nie poddają się destrukcyjnej sile czasu, zachwycając coraz to nowych czytelników w coraz to innych miejscach i epokach. Najbardziej udanym sformułowaniem jest $\mu \nu \eta \mu \varepsilon i \alpha . . . \alpha i \omega ́ v 1 \alpha$ („,wieczno-

76 Diodorus Siculus, Bibliotheca historica, XVII, 71.5 (DS, IV, 245).

77 Hecataeus, FGrHist 264 F 25, w: Diodorus Siculus, Bibliotheca historica, I, 63.5.

78 Wielka Piramida faktycznie pochodzi zczasów IV dynastii (ok. 2575-2465 p.n.e.), więc ci „poniektórzy” dość dokładnie obliczyli jej wiek. Zob. Murphy, The Antiquities of Egypt, 79 nota 121.

79 GLAJJ, 20.

80 Dionysius Halicarnaseus, De compositione verborum, XXV, 31 (Aujac, Denys, III, 184; Madyda, Trzy stylistyki greckie, 261-262). To samo stwierdzenie powtarza się w piśmie Dionizjusza Demostenes. Por. Dionysius Halicarnaseus, Demosthenes, LI, 2 (Aujac, Denys, II, 149). 
trwałe pomniki") ${ }^{81}$, oczywiście chodzi o mowy Demostenesa, efektownie zestawione przez Dionizjusza z pomnikami z marmuru. Sens jest taki, że mowy Demostenesa, znajdujące przez stulecia kolejnych czytelników, są tak samo trwałe jak opierające się upływowi czasu dzieła z kamienia.

\subsection{Wieczne konstelacje}

Diodor odnosi termin aí́vios także do rzeczy bardziej trwałych niż kamień, trwalszych nawet od tradycji, pamięci, ludzkości - mianowicie do zjawisk naturalnych ${ }^{82}$. Są to Słońce, Księżyc i cały kosmos, które „mają wieczną i niezniszczalną

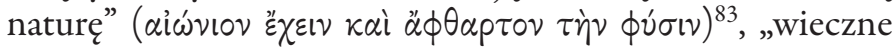
obroty" ( $\pi \varepsilon p i o ́ \delta \omega . . . \alpha i \omega \nu v^{\prime}(\omega)$ ciał niebieskich ${ }^{84}$, „wieczne ru-

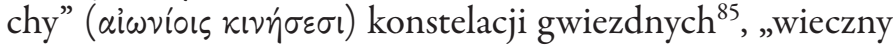

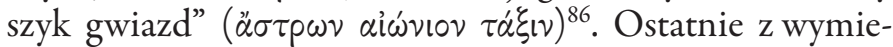
nionych wyrażeń pochodzi od Dionizjusza Skytobrachiona (III wiek p.n.e.), historyka z Mityleny, którego Diodor tu cytuje. Z kolei Dionizjusz Skytobrachion mógł zainspiro-

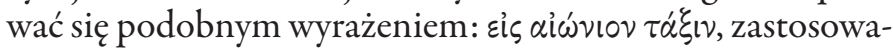
nym przez ateńskiego mówcę Hypereidesa, który w Mowie pogrzebowej z 322 roku p.n.e. odniósł metaforę militarną do życia pozagrobowego (poległy żołnierz stanie „w wiecznym szyku" ${ }^{87}$. Można przypuszczać, że także w pozostałych

81 Dionysius Halicarnaseus, De compositione verborum, XXV, 35 (Aujac, Denys, III, 185; Madyda, Trzy stylistyki greckie, 262).

82 Keizer, Life Time Entirety, 53 nota 153.

83 Diodorus Siculus, Bibliotheca historica, III, 9.1 (DS, I, 277); kontekst: wierzenia Etiopów z okolic Meroe.

84 Diodorus Siculus, Bibliotheca historica, II, 30.6 (DS, I, 220); kontekst: astrologia chaldejska.

85 Diodorus Siculus, Bibliotheca historica, XV, 50.3 (DS, III, 430); kontekst: astrologia chaldejska.

86 Dionysius Scytobrachion, FGrHist 32 F 7, w: Diodorus Siculus, Bibliotheca historica, III, 56.5; kontekst: euhemeryzm.

87 Hyperides, Epitaphius, 27 (Herrman, Hyperides, 48, commentary: 96 n. 183). 
wskazanych miejscach Diodor cytował lub parafrazował historyków III wieku p.n.e.: Manetona - historyku Egiptu i Berossosa - historyka Babilonii. Maneton faktycznie stosował termin ai $\omega^{\prime} v 10 \varsigma$, o czym wiadomo z bardzo dobrego źródła - historyka Apollodora z Aten ( $f$. 150 rok p.n.e. $)^{88}$.

W jeszcze innym miejscu, które opowiada o tym, jak astrologowie chaldejscy przepowiedzieli śmierć Aleksandra Wielkiego w Babilonie, Diodor pisze, że potrafili oni trafnie przewidywać przyszłe wydarzenia dzięki „wiecznej obser-

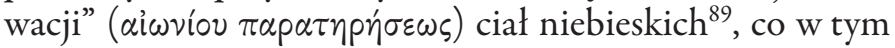
kontekście znaczy: „nieustannej”, „konsekwentnej”, „stałej”. W tym wypadku Diodor mógł korzystać z jednej z wielu zaginionych historii Aleksandra (IV lub III wiek p.n.e.).

\subsection{Hades - wieczysty dom umarłych}

Odnosząc się do światopoglądu Egipcjan, Diodor za swoim źródłem - Hekatajosem z Abdery - twierdzi, że Egipcjanie nazywają własne domy, w których mieszkają, "gospodami”, podczas gdy groby zmarłych nazywają "wieczystymi domami" (åı́́ovs olkovs), dlatego że w tych pierwszych my - żyjący ludzie - przebywamy zaledwie krótki czas (ỏ $\lambda i$ yov xpóvov), podczas gdy zmarli spędzają w Hadesie „nieskoń-

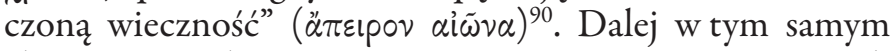
ekscerpcie Hekatajos mówi, że Egipcjanie czczą swoich przodków jako tych, którzy przeprowadzili się „do wie-

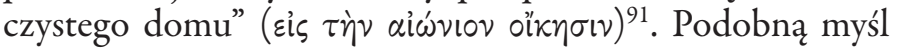

88 Apollodorus Atheniensis, Chronica, fr. 70 (FHG, I, 440); Manetho Sebennyta, Chronica, fr. 7a (FHG, II, 540). Kontekst: pierwszym królem Teb Egipskich był Menes Thinites, co się ttumaczy z egipskiego: „odwiecz-

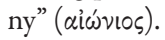

89 Diodorus Siculus, Bibliotheca historica, XVII, 112.2 (DS, IV, 306).

90 Hecataeus, FGrHist 264 F 25, w: Diodorus Siculus, Bibliotheca historica, I, 51.2. Zob. także komentarz do tego miejsca w: Keizer, Life Time Entirety, 53.

91 Hecataeus, FGrHist 264 F 25, w: Diodorus Siculus, Bibliotheca historica, I,93.1.Zob. także komentarz do tego miejsca w: Keizer, Life Time Entirety, 53. 
wyraża nieznany poeta grecko-żydowski Pseudo-Fokylides (okres hellenistyczny lub rzymski), gdy mówi, że Hades jest wspólnym miejscem dla wszystkich, żebraków i książąt, ojczyzną i „domem wieczystym” ( $\mu \varepsilon \dot{\lambda} \lambda \alpha \theta \rho \alpha \delta o ́ \mu \omega \nu$ ai $\left.\omega^{\prime} \nu 1 \alpha\right)^{92}$.

\subsection{Wieczne kary w Hadesie}

Diodor Sycylijski na początku księgi I przedstawia swój własny światopogląd na kwestie eschatologiczne, własny, ale też - jak wykazują uczeni - mocno podbudowany filozofią stoicką ${ }^{93}$. Otóż utrzymuje on, że wszyscy ludzie żyją

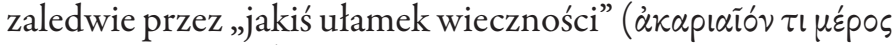

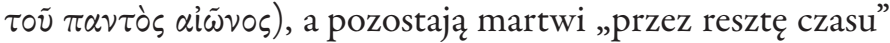

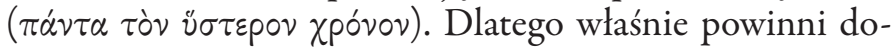
brze wykorzystać dany im krótki czas życia.

Do uczciwego życia zachęcają ich zarówno greckie mity o Hadesie, które są pożyteczne, choć raczej nieprawdziwe, jak i sama historia - prorokini prawdy ${ }^{94}$. Na przykład twierdzi dalej w księdze VIII - bezbożność albo pobożność okazywana bogom za życia wywołuje ich "gniew bez począt-

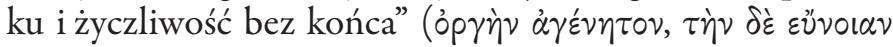
ai $\omega$ viov), które po śmierci skutkują „nieśmiertelną nagrodą

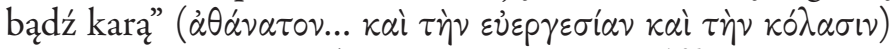
"na całą wieczność" ( powołuje się tu na prawdę objawioną w jakichś misteriach ( $\tau \alpha$ iٓ $\tau \varepsilon \lambda \varepsilon \tau \alpha \tilde{l} \varsigma$ ) i antytetycznie przeciwstawia przymiotnik

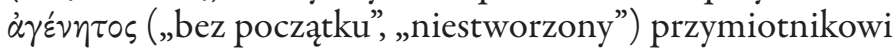

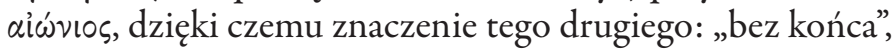
„niekończący się", staje się lepiej uchwytne.

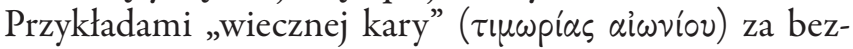
bożność są mityczny Peirithoos - niedoszły porywacz królowej podziemi Persefony i podobno sam Herakles, który mu

92 Pseudo-Phocylides, Sententiae, 112 (van der Horst, The Sentences, 94).

93 Sacks, „Diodoros of Sicily”, 47-48.

94 Diodorus Siculus, Bibliotheca historica, I, 2.2-3 (DS, I, 4).

95 Diodorus Siculus, Bibliotheca historica, VIII, 18.1-3 (DS frs., I, 106). 
towarzyszy196, następnie Iksjon, który spłodził Centaurów $\mathrm{z}$ chmurą w kształcie bogini Hery ${ }^{97}$, oraz Tantal - bezbożny przyjaciel bogów, który zdradzał ludziom ich tajemnice ${ }^{98}$.

Wiemy już, że „wieczna kara” dla Diodora oznaczała karę bez końca. Współczesny Diodorowi autor pseudo-platońskiego Aksjocha podobnie rozumiał „wieczność” kar w Hadesie. Mówi bowiem, że kary w Hadesie trwają "wiecznie” (371e: $\alpha i \omega v i(\omega \varsigma)$, czyli - jak wyjaśnia - „nie mają końca” (371e: $\dot{\alpha} \tau \varepsilon \lambda \varepsilon i \varsigma)^{99}$. Sens $\alpha i \omega ́ \omega v$ lo u Diodora jest więc jasny: jest to coś, co ma początek, ale nie będzie mieć końca. Trudno natomiast jednoznacznie rozstrzygnąć, czy kary dla grzeszników naprawdę nigdy się nie skończą, czy też położy im kres kosmiczny pożar, o którym nauczali popularni w I wieku p.n.e. stoicy.

\subsection{Podsumowanie}

Historycy okresu hellenistycznego stosujący aíwvios obok

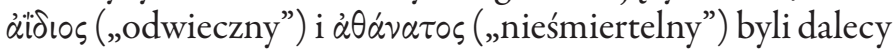
od rozgraniczania znaczenia tych pojęć. U Polibiusza aí́vios wystąpiło tylko jeden raz, u Dionizjusza z Halikarnasu 10 razy, u Diodora Sycylijskiego aż 24 razy. Diodor najwyraźniej upodobał sobie ten wyraz. Używał aí́vilos w różnych kontekstach (w odniesieniu do ludzkiej pamięci, materiałów budowlanych, piramid egipskich, ciał niebieskich, grobów, kar eschatologicznych) i w różnych znaczeniach: „trwały”, „przekazywany z pokolenia na pokolenie”, „wiecznotrwały”, „nieprzerwany”, „wieczysty”, „niekończący się”. Należy uwzględniać fakt, że spora część tych wystąpień pochodzi nie od samego Diodora, lecz od jego hellenistycznych źródeł (historycy Egiptu, historycy Aleksandra Wielkiego).

96 Diodorus Siculus, Bibliotheca historica, IV, 63.4 (DS, I, 498).

97 Diodorus Siculus, Bibliotheca historica, IV, 69.5 (DS, I, 509).

98 Diodorus Siculus, Bibliotheca historica, IV, 74.2 (DS, I, 515).

99 Pseudo-Plato, Axiochus, 371e. 


\section{AISNIOE W LEKSYKOGRAFII BIZANTYŃSKIEJ (V-X WIEK N.E.)}

Niniejszy paragraf wykracza poza ramy chronologiczne wyznaczone dla niniejszego artykułu (IV wiek p.n.e. - I wiek n.e.). Uwzględnienie leksykografii wynika z tego, że odnosi się ona do literatury helleńskiej (tj. niechrześcijańskiej) i przeważnie powiela materiał z wcześniejszych leksykonów datowanych na okres hellenistyczny lub początek okresu Cesarstwa Rzymskiego. Cytowane niżej opracowania leksykograficzne są bardzo trudne lub nawet wręcz niemożliwe do datowania, oprócz Hezychiusza z Aleksandrii (V lub VI wiek n.e.), Etymologicum Genuinum (IX wiek n.e.) i Suidasa (X wiek n.e.).

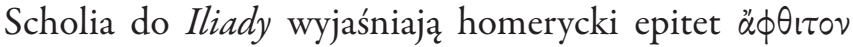
aiıí - użyty na określenie berła Agamemnona, które ten odziedziczył po swoim ojcu - za pomocą syno-

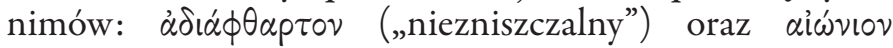
(„wiecznotrwały”) ${ }^{100}$. Tę samą informację powtarza bizantyński leksykon Etymologicum Genuinum ${ }^{101}$.

Hezychiusz z Aleksandrii w swoim zachowanym $\mathrm{Al}$ fabetycznym stowniku wszystkich wyrazów stosuje aí́vios w dwóch miejscach. Pod literą Alpha zamieścił m.in. hasło

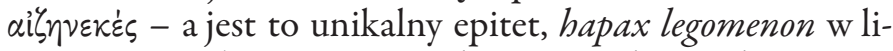
teraturze greckiej, niepoświadczony nigdzie indziej. Tenże rzadki wyraz wyjaśnił przez dwa wyrazy bliskoznaczne:

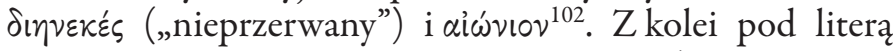
Omikron umieścił m.in. następującą frazę (nie wiadomo,

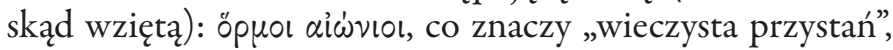
i zinterpretował jako metaforę śmierci ${ }^{103}$.

100 Scholia vetera in Homeri Iliadem, II, 46 (Heyne, Homeri, I, 79).

101 Etymologicum Magnum Genuinum, A, 1467 (Lasserre - Livadaras, Etymologicum, II, 338).

102 Hesychius Alexandrinus, Lexicon, A, 1830 (Latte, Hesychii, I, 66).

103 Hesychius Alexandrinus, Lexicon, O, 1293 (Latte, Hesychii, II, 778). 
Eliusz Herodianus - skądinąd nieznany gramatyk, którego nie należy mylić ze znanym filologiem z II wieku n.e. w księdze Rozbiór gramatyczny zdania wymienił derywaty

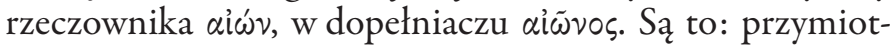

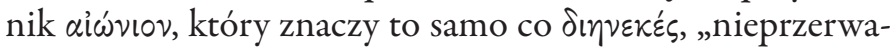
ny", oraz czasownik $\alpha i \omega v i$ 'हlv, który w tym kontekście znaczy „trwać nieprzerwanie” 104 .

Retor Eudemos - także nieznany, różny od perypatetyka Eudemosa z Rodos - wyjaśnił attycki przymiotnik rodzaju żeńskiego à $\gamma$ ńpws („niestarzejąca się” „wiecznie młoda”, „niezniszczalna” $\left.{ }^{105}\right)$ w ten sposób, że jest to osoba, „która się

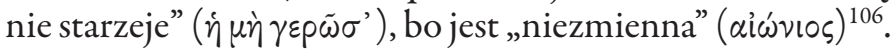

Bizantyński encyklopedysta Suidas stwierdzil, że znaczenie przymiotnika äiòı („wiekuisty”) przekłada się bezpośrednio na przymiotnik aíwvios ${ }^{107}$. Widzieliśmy wyżej na przykładach z literatury klasycznej i hellenistycznej, że te przymiotniki, choć bliskoznaczne, nie były jednak dokładnymi synonimami. Zgodnie z tym pisarze greccy jeszcze w III wieku n.e. rozróżniali ich znaczenia (por. Plotyn, Enneady, III, 7.3). Wydaje się więc, że Suidas nieco uprościł problem.

Zakończmy na Etymologicum Gudianum, leksykonie bizantyńskim znanym z kodeksu z Otranto (Vat. Barb. gr. 70) z XI wieku n.e. ${ }^{108}$ Ten leksykon podaje pod literą Alpha na-

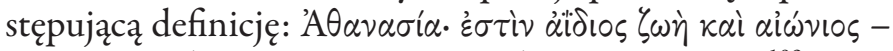
"Nieśmiertelność: to jest życie wiekuiste i wieczne" ${ }^{109}$.

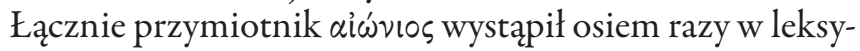
konach bizantyńskich i ani razu w zachowanych ze starożytności leksykonach dialektu attyckiego.

104 Pseudo-Aelius Herodianus, Partitiones, AI (Boissonade, Herodiani, 26).

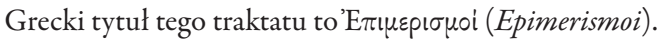

105 To ostatnie znaczenie podpowiada księga Suidasa. Por. Suidae Lexicon, A, 227 (Adler, Suidae, I, 26).

106 Niese, „Excerpta ex Eudemi codice Parisino n. 2635”, 148, fol. 3 b.

107 Suidae Lexicon, A, 673 (Adler, Suidae, I, 65).

108 Tosi, „Typology of Lexicographical Works”, 634.

109 Etymologicum Gudianum, cod. Z (de Stefani, Etymologicum, 30). 
7. ZNACZENIE AISNIOE W OMAWIANYCH TEKSTACH (KONKLUZJA)

1. Przedmiotem niniejszego artykułu była semantyka wy-

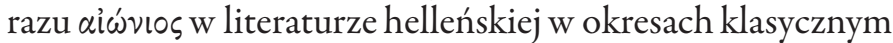
i hellenistycznym do czasu powstania Nowego Testamentu (IV wiek p.n.e. - I wiek n.e.). W tekstach literackich zachowanych z tego okresu (Corpus Platonicum, hellenistyczna

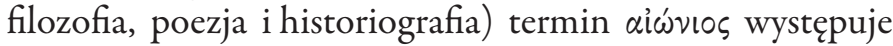
łącznie 60 razy.

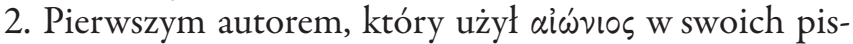
mach, był Platon. On jednak nie wynalazł tego terminu, lecz prawdopodobnie przejął od sekty orfików, którzy do

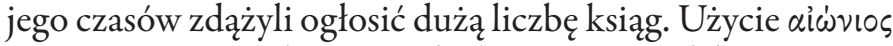
przez pitagorejczyków przed Platonem jest słabo potwier-

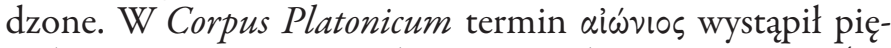
ciokrotnie w następujących znaczeniach: „niezmienny” (jeden raz o paradygmacie, jeden raz o czasie); „niepodlegający narodzinom i śmierci” (jeden raz o bogach); „niekończący się" (jeden raz o eschatologicznej nagrodzie, tj. zapowiedzianym przez orfickiego proroka pijaństwie); „bez końca” (jeden raz o eschatologicznych karach).

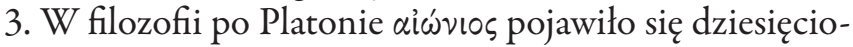
krotnie w kilku różnych konotacjach: „dożywotni” (jeden raz o cierpieniu); „niekończący się” (trzy razy o domniemanych cierpieniach eschatologicznych); „cykliczny” (jeden raz o odradzających się światach, jeden raz o przypływach); „trwający do końca świata” (jeden raz o karach w Hadesie); "przekazywany z pokolenia na pokolenie” (jeden raz o sławie - to wystapienie jest cytatem z historyka Diodora); „niezmienny” w takim sensie jak u Platona (jeden raz o paradygmacie); „wieczny” w sensie absolutnym (jeden raz o Bogu).

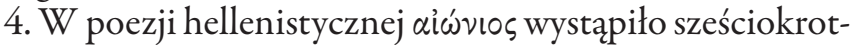
nie, jeśli włączyć do niej utwory o niepewnej dacie: Hymny orfickie i Sentencje Pseudo-Fokylidesa. U Kallimacha termin 
ten wystąpił dwukrotnie w sensie: „dozgonny” (o dziewictwie) i „nieustanny” (o odplywie rzeki). W Hymnach orfickich wyraz ten został użyty trzykrotnie w znaczeniach: „wiecznotrwały” (dwa razy o Słońcu); „wieczysty” (jeden raz o śnie - metaforze śmierci). U Pseudo-Fokylidesa aí́vios znaczy „wieczysty” (o Hadesie - wspólnym domu dla wszystkich zmarłych).

5. W historiografii hellenistycznej termin aíuvios został użyty aż 35 razy. Zakres semantyczny wyrazu jest następujący: „trwały” (dziewięć razy o zbiorowej pamięci); „przekazywany z pokolenia na pokolenie" (11 razy o kulcie bogów, o pochwale, o sławie, o niesławie, o nienawiści, o waśni); „wiecznotrwały” (pięć razy o kamieniach, o piramidach egipskich, o mowach Demostenesa); "niezniszczalny” (cztery razy o ciałach niebieskich); „nieustanny” (jeden raz o obserwacji ciał niebieskich); „wieczysty” (jeden raz o grobach - mieszkaniach zmarlych); „nieskończony” (jeden raz o łaskawości bogów wobec pobożnych ludzi); „niekończący się" (trzy razy o karach odbywanych przez bezbożników w Hadesie). Do tego trzeba doliczyć cztery wystąpienia: jedno u attyckiego mówcy Hypereidesa: („wieczysty”, o szyku bojowym, w którym ma stanąć poległy żołnierz); drugie u historyka Manetona („odwieczny”, o pierwszym królu Teb Egipskich); trzecie u retora Pseudo-Longinusa („niezmienny”, o bogach), czwarte u astronoma Geminusa („niezniszczalne", o ciałach niebieskich).

6. Bizantyńskie leksykony (V-X wiek n.e.) stosują termin $\alpha i \omega v v$ os osiem razy jako synonim następujących pojęć: "wiecznotrwały" (dwa razy o berle Agamemnona); „wieczysty" (jeden raz o metaforycznej przystani, czyli śmierci); „nieprzerwany” (dwa razy); "niezniszczalny” (jeden raz); „wiekuisty” (jeden raz); „nieśmiertelny” (jeden raz).

7. Przegląd znaczeń pokazuje, że w literaturze helleńskiej przed powstaniem Nowego Testamentu termin aí่vios nie oznaczał „wieczny”. Jedyny wyjątek od tej reguły znajduje się u Pseudo-Timajosa i może być wyjaśniony wpływem fi- 
lozofii i frazeologii Filona Aleksandryjskiego, który z kolei zależał od Septuaginty.

\section{BIBLIOGRAFIA}

Adler, A., Suidae Lexicon (Lexicographi Graeci 1; Lipsiae: Teubneri 1928) I.

Arrighetti, G., Epicuro: Opere (Classici della Filosofia 4; Torino: Einaudi 1960).

Aujac, G. - Lebel, M., Denys d'Halicarnasse: Opuscules rhétoriques (Collection des Universités de France, Série grecque; Paris: Belles Lettres 1978-1992) I-V.

Beekes, R.S., Etymological Dictionary of Greek (Leiden Indo-European Etymological Dictionary Series 10; Leiden: Brill 2010) (=Beekes).

Bernabé, A., Poetae epici Graeci: testimonia et fragmenta. II/1.

Orphicorum et Orphicis similium testimonia et fragmenta. II/3. Musaeus; Linus; Epimenides; Papyrus Derveni; Indices (BSGRT; Monachii et Lipsiae: Saur - Berolini: de Gruyter 2004-2007) (=PEG).

Boissonade, J.F., Herodiani Partitiones: E codd. Parisinis (Londini: Valpianis 1819).

Büttner-Wobst, Th., Polybii Historiae, wyd. 2 (BSGRT; Stutgardiae: Teubneri 1995) II.

Chantraine, P. et al., Dictionnaire étymologique de la langue grecque: histoire des mots (Paris: Klincksieck 1968-1980) I-IV (=Chantraine).

de Stefani, A., Etymologicum Gudianum quod vocatur (Lipsiae: Teubneri 1909) I.

Diels, H. - Kranz, W., Die Fragmente der Vorsokratiker, wyd. 6 (Berlin: Weidmann 1951-1952) I-III (=D-K).

Fayant, M.-C., Hymnes orphiques (Collection des Universités de France. Série grecque 509; Budé; Paris: Les Belles Lettres 2014). 
Goukowsky, P. - Cohen-Skalli, A., Diodore de Sicile: Bibliothèque historique: Fragments (Collection des Universités de France; Paris: Belles Lettres 2006-2014) I-IV (=DS frs.).

Hammer, S. - Brożek, M., Polibiusz: Dzieje (Biblioteka Przekładów z Literatury Antycznej 3; Wrocław: Ossolineum 1957) I.

Herrman, J., Hyperides: Funeral Oration (American Classical Studies 53; Oxford: Oxford University Press 2009).

Heyne, C.G., Homeri Ilias; Scholia minora; Heraclidis Allegoriae Homericae (Oxonii: E typographeo Clarendoniano 1821) I.

Isnardi Parente, M., Senocrate e Ermodoro: Testimonianze e frammenti, wyd. 2 (Testi e Commenti 13; Pisa: Edizioni della Normale 2012).

Jacoby, C., Dionysii Halicarnasei Antiquitatum Romanarum quae supersunt, wyd. 2 (BSGRT; Stutgardiae - Lipsiae: Teubneri 1995-1998) I-V (=DH).

Jacoby, F. et al., Die Fragmente der griechischen Historiker (Berlin: Weidmann 1923-) I-(=FGrHist).

Keizer, H.M., Life Time Entirety: A Study of $\mathrm{AI} \Omega \mathrm{N}$ in Greek Literature and Philosophy, the Septuagint and Philo (Diss. Universiteit van Amsterdam 1999).

Krońska, I. et al., Diogenes Laertios: Żywoty i poglady stynnych filozofów, wyd. 3 (Warszawa: Państwowe Wydawnictwo Naukowe 1984).

Lasserre, F. - Livadaras, N., Etymologicum Magnum Genuinum (Athens: Parnassos 1992) II.

Latte, K., Hesychii Alexandrini Lexicon (Hauniae: Munksgaard 1953-1966) I-II.

Liddell, H.G. - Scott, R. - Jones, H.S., Greek-English Lexicon, wyd. 9 (Oxford: Clarendon 1996) (=LSJ).

Ławińska-Tyszkowska, J. et al., Kallimach: Dzieta poetyckie. I. Hymny i epigramaty (Biblioteka Antyczna 49; Wrocław: Uniwersytet Wrocławski 2016). 
Madyda, W., Trzy stylistyki greckie: Arystoteles, Demetriusz, Dionizjusz (Biblioteka Narodowa II 75; Wrocław: Ossolineum 1953).

Manitius, C., Gemini Elementa astronomiae, wyd. 2 (BSGRT; Stutgardiae: Teubneri 1974).

Mason, A.S., „Why Does Plato Believe in a Timeless Eternity?", New Essays on Plato: Language and Thought in Fourth-Century Greek Philosophy (red. F.-G. Herrmann) (Swansea: The Classical Press of Wales 2006) 177-188.

Mohr, R.D., „Plato on Time and Eternity”, Ancient Philosophy 6 (1986) 39-46.

Montanari, F. et al., The Brill Dictionary of Ancient Greek (Leiden: Brill 2015) (=Montanari).

Müllerus, C., Fragmenta historicorum Graecorum (Paris: Didot 1841-1884) I-V (=FHG).

Murphy, E., The Antiquities of Egypt: A Translation with Notes of Book I of the 'Library of History' of Diodorus Siculus, wyd. 2 (New Brunswick, NJ - London: Transaction 1990).

Niese, B., „Excerpta ex Eudemi Codice Parisino n. 2635”, Philologus suppl. 15 (1922) 145-160.

Obbink, D., Philodemus On Piety (Oxford: Clarendon 1996) I. Orbán, A.P., Les dénominations du monde chez les premiers auteurs chrétiens (Graecitas Christianorum Primaeva 4; Nijmegan: Dekker 1970).

Pfeiffer, R., Callimachus. II. Hymni et epigrammata (Oxonii: E typographeo Clarendoniano 1953).

Podbielski, H. - Narecki, K., Trzy greckie stylistyki i dwa traktaty retoryczne z okresu Cesarstwa Rzymskiego. Pseudo-Longinus; Pseudo-Arystydes; Anonymus Seguerianus; Apsines (Źródła i Monografie 429; Lublin: TN KUL 2016).

Ramelli, I. - Konstan, D., Terms for Eternity: Aionios and Aidios in Classical and Christian Texts (Piscataway, NY: Gorgias 2007).

Sacks, K.S., „Diodoros of Sicily and the Hellenistic Mind”, Diodoros of Sicily: Historiographical Theory and Practice in 
the Bibliotheke (red. L.I. Hau - A. Meeus - B. Sheridan)

(Studia Hellenistica 58; Leuven: Peeters 2018) 43-63.

Smith, A., Porphyrii Philosophi fragmenta (BSGRT; Stuttgart:

Teubner 1993).

Stern, M., Greek and Latin Authors on Jews and Judaism.

I. From Herodotus to Plutarch (Publications of the Israel Academy of Sciences and Humanities; Jerusalem: Israel Academy of Sciences and Humanities 1976) (=GLAJJ).

Theiler, W., Posidonios: Die Fragmente (Texte und Kommentare 10/1; Berlin: de Gruyter 1982) I.

Thesleff, H., The Pythagorean Texts of the Hellenistic Period (Acta Academiae Aboensis. Ser. A, Humaniora 30/1; Åbo: Åbo Akademi 1965).

Tobin, T.H., Timaios of Locri: On the Nature of the World and the Soul (Texts and Translations 26. Graeco-Roman Religion Series 8; Chico, CA: Scholars Press 1985).

Tosi, R., „Typology of Lexicographical Works”, Brill's Companion to Ancient Greek Scholarship (red. F. Montanari S. Matthaios - A. Rengakos) (Brill's Companions in Classical Studies; Leiden: Brill 2015) I, 622-636.

van der Horst, P.W., The Sentences of Pseudo-Phocylides (Studia in Veteris Testamenti Pseudepigrapha 4; Leiden: Brill 1978). Vogel, F. - Fischer, C.T., Diodorus: Bibliotheca historica, wyd. 3 (BSGRT; Stutgardiae: Teubneri 1985) I-V (=DS).

von Arnim, I., Stoicorum veterum fragmenta (Stutgardiae: Teubneri 1903-1924) I-IV (=SVF).

Wozniczka, P., „Diodoros' Narrative of the First Sicilian Slave Revolt (c. 140/35-132 B.C.) - A Reflection of Poseidonios' Ideas and Style?", Diodoros of Sicily: Historiographical Theory and Practice in the Bibliotheke (red. L.I. Hau A. Meeus - B. Sheridan) (Studia Hellenistica 58; Leuven: Peeters 2018) 221-246.

Wuensch, R., Ioannis Laurentii Lydi Liber de mensibus (BSGRT; Leipzig: Teubner 1898). 
Zarewicz, D., Przywotywanie bogów - mit, magia, misteria wstarożytnej Grecji (Warszawa: Wydawnictwo Naukowe Sub Lupa 2017).

Żybert, E., Hymny orfickie (Bibliotheca Curiosa 6; Wrocław: Atut 2012).

Ewa Osek, filolog klasyczny, pracownik naukowo-dydaktyczny w Instytucie Literaturoznawstwa KUL, doktor habilitowany nauk humanistycznych w dyscyplinie literaturoznawstwo, profesor nadzwyczajny KUL, członek International Society for Neoplatonic Studies. Główny obszar zainteresowań: filologia klasyczna, literatura starogrecka, religia w literaturze późnego antyku, tak zwana literatura orficka, neoplatonizm. Autorka kilku książek, kilkudziesięciu artykułów naukowych oraz kilkunastu tłumaczeń tekstów autorów starogreckich, m.in. Platona, Porfiriusza z Tyru, Marinusa z Samarii. Uczestniczyła czynnie w wielu konferencjach naukowych w Polsce i zagranicą. 
